\title{
Effect of mydriatic and cycloplegic drugis in glaucomatous and nonglaucomatous eyes using ultrasound biomicroscopy
}

\author{
Efeito dedrogas midriáticas e cicloplégicas em olhos glaucomatosose \\ nãoglaucomatosos usando a biomicroscopia ultra-sônica
}

Danielle Britto Miranda Silva ${ }^{(1)}$

Norma Allemann (2)

Paulo Augusto de Arruda Mello ${ }^{(3)}$

\section{SUMMARY}

Purpose: To study the anatomical relationships of the anterior segment of the eye, using ultrasound biomicroscopy in patients with chronic simple glaucoma and nonglaucomatous eyes, after mydriatic and cycloplegic instillation.

Patients and Methods: Thirty eyes with chronic simple glaucoma and 30 nonglaucomatous eyes were studied. Anterior chamber depth, irislens contact and iris-zonule distance were measured, in both groups, using ultrasound biomicroscopy, in the three following conditions: without mydriatic and cycloplegic instillation, with $1 \%$ tropicamide alone and with $1 \%$ tropicamide plus $10 \%$ phenylephrine chlorhydrate.

Results: Ultrasound biomicroscopy examinations of glaucomatous and nonglaucomatous eyes, without mydriatic and cycloplegic instillation, showed no statistically significant difference in the central anterior chamber depth, iris-lens contact and iris-zonule distance. The difference between examinations without mydriatic and cycloplegic instillation, with $1 \%$ tropicamide and with $1 \%$ tropicamide plus $10 \%$ phenylephrine chlorhydrate was statistically significant regarding the variables measured in both groups.

Conclusions: No anatomical difference was observed between the anterior segment of glaucomatous and nonglaucomatous eyes after mydriatic and cycloplegic instillation. The results of this clinical investigation, using ultrasound biomicroscopy were innovative, allowing a dynamic and quantitative evaluation of the anatomical relationships between intraocular structures when submitted to mydriasis and cycloplegy, which up to now were only qualitative.

Key words: Anterior segment of the eye; Ultrasonography; Glaucoma; Open-angle; Mydriatics; Cycloplegics.

\section{INTRODUCTION}

The advent of ultrasound biomicroscopy (UBM) expanded echographic studies in vivo of the anterior segment structures of the eye and their anatomical relationships with maximum depth at the ciliary body, peripheral retina and vitreous ${ }^{1,2}$. The UBM examination using a $50 \mathrm{MHz}$ transducer, allows a $5 \mathrm{~mm}$ penetration but with a $37 \mu \mathrm{m}$ microscopic resolution ${ }^{3}$.

The UBM technique turned to be useful in research and clinical practice of glaucoma, because serial observations of different stages of the disease can be obtained ${ }^{4}$. Extending this method to glaucomatous eyes allows to 
get a view and to measure the relationship between the anatomical structures of the anterior segment among these eyes, since the cause of several types of glaucoma is a structural component and possibly may be explained using this technique ${ }^{5}$.

The mydriatic and cycloplegic solutions have been used for pupil dilation as a routine in ophthalmic practice. It is therefore significant to note that these drugs also have the ability to raise the intraocular pressure (IOP) in eyes with open angles specially when they are glaucomatous. Some eyes with open angle glaucoma may develop increased intraocular pressure while under mydriasis even though no angle narrowing occurs. No matter what the true mechanism of this response, it is obvious that significant increases in intraocular pressure under cycloplegia are not the province of angle closure glaucoma alone ${ }^{6}$.

The objective of this study is to evaluate, by means of ultrasound biomicroscopy, the anterior segment of the eye of the patient with chronic simple glaucoma and nonglaucomatous eyes after mydriatic and cycloplegic instillation.

\section{PATIENTS AND METHODS}

Sixty eyes were selected and divided into two groups: group $\mathrm{G}$ consisting of 30 eyes with chronic simple glaucoma (CSG) and group NG, consisting of 30 nonglaucomatous eyes. Group $\mathrm{G}$ presented IOP $\geq 21 \mathrm{mmHg}$; open and wide anterior chamber angle; alterations of the optic disk and visual field; and was under recent medical control with $0.5 \%$ timolol maleate eyedrops associated or not with $2 \%$ pilocarpine chlorhydrate eyedrops. Patients of both groups were white and their irises were brown. The protocol of this investigation was approved by the Medical Ethics Committee of the Federal University of São Paulo, Brazil.

Patients were excluded when they presented: evidence of diseases which would alter pupillary response; high risk of CSG: IOP without clinical control; and/or excavation/disk ratio equal to or higher than 0.8 ; and/or unilateral amaurosis and/or extensive glaucomatous damages in the visual field; severe hypertension, arrhythmia, hyperthyroidism, myocardiopathies and arteriosclerosis; hypersensitivity to the used drugs; corneal abnormalities; previous eye surgeries; ametropia over 7 diopters in spherical equivalent; lack of cooperation during the examinations.

Patients using topical $0.5 \%$ timolol maleate discontinued the drug during 4 weeks while those using topical $2 \%$ pilocarpine chlorhydrate, one week previous to UBM. Two solutions were used for pupil dilation: $1 \%$ tropicamide and 1\% tropicamide plus $10 \%$ phenylephrine chlorhydrate. One drop of each solution was instilled in each eye and was repeated once after ten minutes. All the examinations were made after 30 minutes of the first drop.

An UBM system model 840 (Humphrey Instruments Inc.) with a $50 \mathrm{MHz}$ transducer was used to carry out the UBM examinations. All the examinations were made under indirect light, with a $15 \mathrm{~V}-15 \mathrm{~W}$ light source. The patient was submitted to a previous UBM examination (Prev) without drug instillation. On the same day, after using 1\% tropicamide, a second examination was carried out $(\mathrm{C} 1)$. A week later, a third UBM examination (C2) was performed after using 1\% tropicamide plus $10 \%$ phenylephrine.

The images obtained by the UBM examinations were recorded for later analysis and measurements of the following structures (Figure 1): 1. Anterior chamber depth, in micra $(\mu \mathrm{m})$, measured in the central region, corresponding to the axial distance between the echo of the endothelial surface of the cornea and the anterior capsule of the lens ${ }^{2} .2$. Contact of the iris with the anterior capsule of the lens, in $\mu \mathrm{m}$, measured clockwise in the 12, 3, 6 and 9 regions $^{2}$. 3. Iris-zonule distance measured clockwise in the 12,3, 6 and 9 regions, in $\mu \mathrm{m}$, tracing a perpendicular straight line between the iris epithelium and the anterior zonule, at its junction with the ciliary process.

Friedman's test was used for group G and group NG, to compare the variables of the Prev, $\mathrm{C} 1$ and $\mathrm{C} 2$ examinations and the 12, 3, 6 and 9 regions for each examination. Mann-Whitney's test was applied to compare groups $\mathrm{G}$ and NG regarding the variables studied by the Prev examination ${ }^{7}$. Level of significance was $\mathrm{p}<0.05$.

\section{RESULTS}

Group $\mathrm{G}$ consisted of 30 eyes of 17 patients with CSG, age ranged from 43 to 78 years with a mean of 63 years. Nine patients were males and eight females. Ametropia ranged from -4.38 to $+3.50 \mathrm{Sph}$ and there was no cylinder greater than -2.75 diopters. Group NG consisted of 30 nonglaucomatous eyes of 16 patients, age ranging from 38 to 73 years with a mean of 60 years. Seven patients were males and nine females. Ametropia ranged from -4.0 to $+2.62 \mathrm{Sph}$ and there was no cylinder greater than -1.25 diopters.

No significant difference was found (Mann Whitney test, $p>0.05$ ) between the anterior chamber depth of groups $G$ and $\mathrm{NG}$ at the previous examinations (Prev). A significant increase in the anterior chamber depth of both groups was observed (Friedman test, $\mathrm{p}<0.05$ ) when comparing the previous examination (Prev), with the examination after instillation of $1 \%$ tropicamide $(\mathrm{C} 1)$ and after instillation of $1 \%$ tropicamide plus $10 \%$ phenylephrine chlorhydrate (C2) (Table 1).

No significant difference of the iris-lens contact and iriszonule distance was observed (Mann Whitney test, $\mathrm{p}>0.05$ ) between the groups $\mathrm{G}$ and $\mathrm{NG}$ in the 12, 3, 6 and 9 regions at the previous examination (Prev). A statistically significant decrease in iris-lens contact and iris-zonule distance in the 12, 3,6 and 9 regions was observed in the studied groups, comparing the previous examinations (Prev), with those using 1\% tropicamide $(\mathrm{C} 1)$ and with those using 1\% tropicamide plus $10 \%$ phenylephrine chlorhydrate (C2) and also on comparison of the two latter (Friedman test, $\mathrm{p}<0.05$ ) (Table 2 and 3 ). 

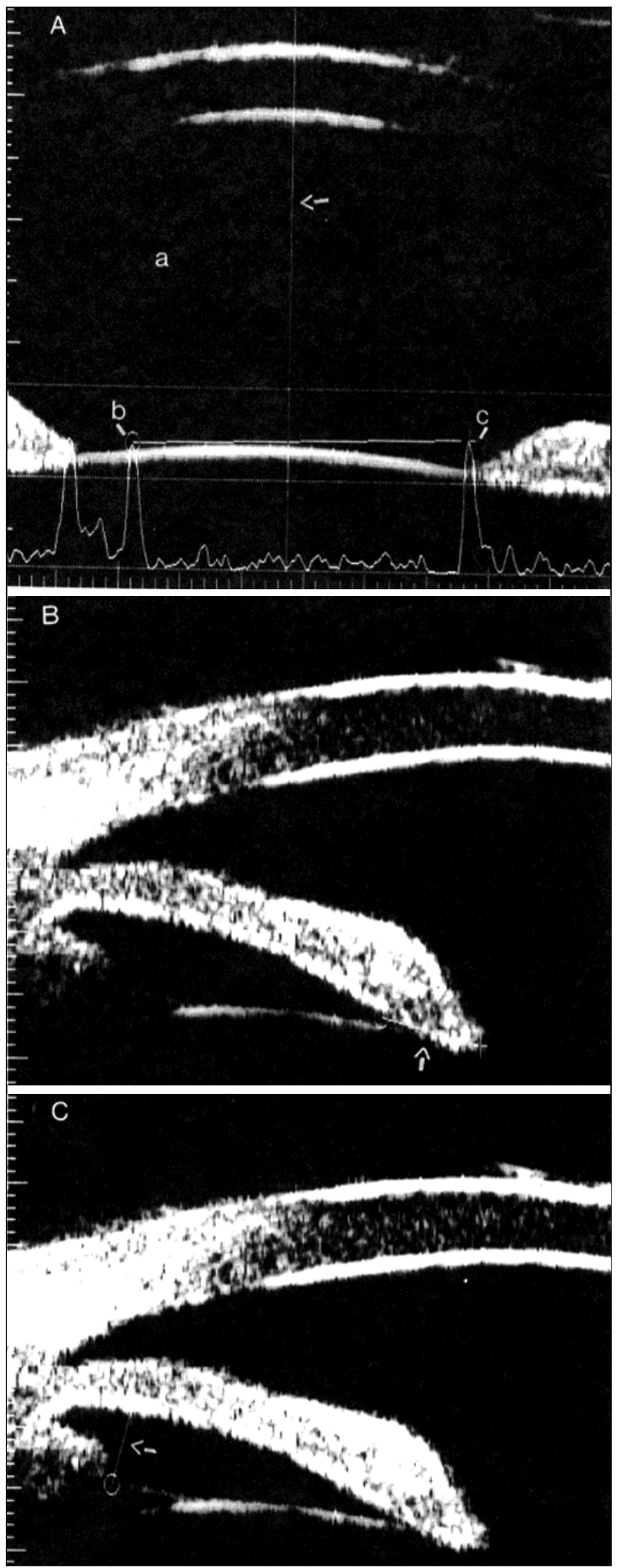

Figure 1 - A) Central measurement of anterior chamber depth of a glaucomatous eye at the previous examination. The vector (arrow) is positioned at (a) the central area of the anterior chamber. Mode A was used to measure the distance from the peak (b) referring to the Descemet membrane /endothelium to (c) the peak referring to the anterior surface of the lens and the result being $X=2.726 \mathrm{~mm}$ or 2726 $\mu \mathrm{m}$. B) Measure of the iris-lens contact of a glaucomatous eye at the previous examination obtained along the extension of the surface of the iris-lens contact (arrow), the result being lengh $(L)=0.848 \mathrm{~mm}$ or $848 \mu \mathrm{m}$. C) Measure of the iris-zonule distance of a glaucomatous eye at the previous examination obtained by drawing a perpendicular line from the anterior zonule to the posterior face of the iris (arrow), the result being lengh $(L)=0.622 \mathrm{~mm}$ ou $622 \mu \mathrm{m}$.
Table 1. Results of the mean of the anterior chamber depth measurements $(\mu \mathrm{m})$ of glaucomatous (G) and nonglaucomatous (NG) eyes at the previous examinations (Prev), with $1 \%$ tropicamide eyedrops $(\mathrm{C} 1)$ and with $1 \%$ tropicamide plus $10 \%$ phenylephrine chlorydrate (C2).

\begin{tabular}{|c|c|c|}
\hline & $\underset{(\mu \mathrm{m})}{\mathbf{G}}$ & $\begin{array}{c}\mathbf{N G} \\
(\mu \mathrm{m})\end{array}$ \\
\hline Prev & 3046 & 3019 \\
\hline C1 & 3111 & 3114 \\
\hline C2 & 3097 & 3085 \\
\hline
\end{tabular}

Table 2. Results of the mean of the iris-lens contact measurements $(\mu \mathrm{m})$ in the 12, 3, 6 and 9 regions of glaucomatous $(G)$ and nonglaucomatous (NG) eyes in the previous examinations (Prev), with $1 \%$ tropicamide eyedrops (C1) and with $1 \%$ tropicamide plus $10 \%$ phenylephrine chlorydrate (C2).

\begin{tabular}{|c|c|c|c|}
\hline & & $\underset{(\mu \mathbf{m})}{\mathbf{G}}$ & $\begin{array}{c}\text { NG } \\
(\mu \mathrm{m})\end{array}$ \\
\hline & 12 & 1313 & 1187 \\
\hline \multirow[t]{3}{*}{ Prev } & 3 & 1292 & 1203 \\
\hline & 6 & 1309 & 1204 \\
\hline & 9 & 1273 & 1220 \\
\hline \multirow{4}{*}{ C1 } & 12 & 681 & 546 \\
\hline & 3 & 672 & 550 \\
\hline & 6 & 654 & 549 \\
\hline & 9 & 635 & 519 \\
\hline \multirow{4}{*}{$\mathrm{C} 2$} & 12 & 383 & 319 \\
\hline & 3 & 358 & 330 \\
\hline & 6 & 368 & 327 \\
\hline & 9 & 371 & 344 \\
\hline
\end{tabular}

Table 3. Results of the mean of the iris-zonule distance measurements $(\mu \mathrm{m})$ in the $12,3,6$ and 9 regions of glaucomatous $(G)$ and nonglaucomatous (NG) eyes, at the previous examinations (Prev), with $1 \%$ tropicamide eyedrops (C1) and with $1 \%$ tropicamide plus $10 \%$ phenylephrine chlorydrate (C2).

\begin{tabular}{|c|c|c|c|}
\hline & & $\underset{(\mu \mathrm{m})}{\mathrm{G}}$ & $\begin{array}{c}\text { NG } \\
(\mu \mathrm{m})\end{array}$ \\
\hline & 12 & 622 & 617 \\
\hline Prev & 3 & 612 & 636 \\
\hline & 6 & 604 & 640 \\
\hline & 9 & 581 & 612 \\
\hline & 12 & 488 & 528 \\
\hline C1 & 3 & 488 & 503 \\
\hline & 6 & 503 & 494 \\
\hline & 9 & 476 & 493 \\
\hline & 12 & 399 & 413 \\
\hline $\mathrm{C} 2$ & 3 & 401 & 406 \\
\hline & 6 & 417 & 404 \\
\hline & 9 & 403 & 402 \\
\hline
\end{tabular}

There was no significant difference between the measurements of ocular structures, such as, iris-lens contact and iriszonule distance at the previous examinations (Prev), with $1 \%$ tropicamide $(\mathrm{C} 1)$ and with $1 \%$ tropicamide plus $10 \%$ phenylephrine chlorydrate $(\mathrm{C} 2)$ in the 12, 3, 6 and 9 regions of each studied eye (Friedman test, $\mathrm{p}>0.05$ ). 


\section{DISCUSSION}

Elevation of IOP by many mydriatic and cycloplegic drugs has been reported to occur in eyes in which the filtration angle remained open during mydriasis. The incidence of pressure elevation of $6 \mathrm{mmHg}$ or more is $23 \%$ in a population with open angle glaucoma and $2 \%$ in apparently normal population ${ }^{6}$.

Conventional $10 \mathrm{MHz}$ ultrasonography is capable of measuring relatively large distances such as anterior chamber depth; however, ultrasound biomicroscopy increases accuracy because of finer positioning endpoints and an improved exact measurement position ${ }^{2}$.

In a biometry study of cataractous eyes the mean anterior depth in the phakic eyes was $3.24 \pm 0.44 \mathrm{~mm}^{1}$.

The UBM technique produces sections of the living human eye, at microscopic resolution without violating the integrity of the globe ${ }^{2}$. This technique allowed to define the profile of the anterior chamber extension. The measurement of the anterior chamber depth is not restricted to the axial position and corresponds to any point from the endothelial face to the sur-face of the iris or lens ${ }^{5}$.

In this study, the axial anterior chamber depth was similar in the previous examinations (Prev) of groups $\mathrm{G}$ (mean, 3046 $\mu \mathrm{m})$ and NG (mean, $3019 \mu \mathrm{m}$ ). This result agrees with that found in nine normal individuals in which the axial measurement of the anterior chamber depth using UBM was $3128 \pm 372$ $\mu \mathrm{m}^{2}$. An increase in the anterior chamber depth was observed by the UBM technique after the use of mydriatics and cycloplegics in groups $\mathrm{G}$ and $\mathrm{NG}$, corroborating the findings of the literature ${ }^{8}$. But the difference of the anterior chamber depth between the examinations with $1 \%$ tropicamide $(\mathrm{C} 1)$ and with $1 \%$ tropicamide plus $10 \%$ phenylephrine chlorydrate $(\mathrm{C} 2)$ was not significant. In the investigated literature, no studies using a similar method which would allow a comparison with our results were found.

The iris is positioned on the lens at the pupillary border and this contact area may be measured using UBM examination. However, any space which may exist between the iris and the lens is too small to be detected ${ }^{9}$. On the other hand, the aqueous humor could not escape from the posterior chamber of the eye if there would be a constant iris-lens contact in all meridians. It is assumed that the iris-lens separation is well below the power of resolution of the equipment used in the UBM and, therefore, is not observed ${ }^{10}$. In this study, no significant difference of the iris-lens contact was observed in the 12, 3, 6 and 9 regions between the groups $\mathrm{G}$ (mean, 1297 $\mu \mathrm{m})$ and NG (mean, $1206 \mu \mathrm{m}$ ) at the previous examinations (Prev). Such results are similar to those found in nine normal individuals in which the iris-lens contact using UBM technique was $1388 \pm 370 \mu \mathrm{m}^{2}$.

Regarding the iris-lens contact, the response to the use of mydriatic and cycloplegic drugs was greater after the use of $1 \%$ tropicamide plus $10 \%$ phenylephrine chlorydrate in both groups $(\mathrm{C} 2)$. These results agreed with those of the literature, reporting that when mydriasis increases, the area of the posterior face of the iris in contact with the lens capsule decreases. On the other hand, cycloplegia reduces convexity and thickness of the lens ${ }^{11}$.

The iris-zonule distance limits the compartment formed by the posterior face of the iris, cilliary body, anterior zonule and anterior capsule of the lens. The iris-zonule distance was similar in the previous examinations (Prev) in groups $\mathrm{G}$ (mean, $605 \mu \mathrm{m}$ ) and NG (mean, $626 \mu \mathrm{m}$ ). Such results are similar to those found in normal eyes in which the measurement of the iris-zonule distance with the UBM technique was $671 \pm 124 \mu \mathrm{m}$ 2

In this study, images with the same conditions of the examinations were used and measured in several regions of the eye by the same observer. There was no significant difference between the measurements of ocular structures, such as, iris-lens contact and iris-zonule distance at the previous examinations (Prev), with $1 \%$ tropicamide (C1) and with $1 \%$ tropicamide plus $10 \%$ phenylephrine chlorydrate $(\mathrm{C} 2)$ in the $12,3,6$ and 9 regions of each studied eye. The small differences may, on the other hand, show the dynamics of the mydriatic and cycloplegic status between the several regions of the eye at the same examination. The variable of the anterior chamber depth was measured only in the axial position but all the previous conditions established for each examination were observed.

The results obtained in this investigation agreed with gonioscopic and histological findings of the literature, corroborated the pharmacological and biomechanical action of the studied mydriatic and cycloplegic drugs as well as allowed a dynamic and quantitative evaluation of the anatomical relationships of intraocular structures in normal and glaucomatous eyes.

The UBM equipment is valuable in the conduction of clinical investigation of glaucoma. Eyes under cycloplegia whose angles remained open but whose intraocular pressure rose also displayed a simultaneous decrease in outflow facility. Some authors speculated that such a decrease in aquous outflow values produced by cycloplegia is due to decrease in the tonus of the ciliary muscle ${ }^{6}$. However, in this study, no anatomical difference was observed between the anterior segment of glaucomatous and nonglaucomatous eyes after mydriatic and cycloplegic instillation.

\section{RESUMO}

Objetivo: Estudar por meio da biomicroscopia ultra-sônica, as relações anatômicas das estruturas do segmento anterior dos olhos de pacientes portadores de glaucoma crônico simples e não-glaucomatosos, após a instilação de midriá-ticos e cicloplégicos.

Pacientes e métodos: Foram estudados 30 olhos com glaucoma crônico simples e 30 olhos não-glaucomatosos. A profundidade da câmara anterior, o toque iris-cristalino 
e a distância íris-zônula foram analisados pela biomicroscopia ultra-sônica sem a instilação de midriáticos e cicloplégicos, com tropicamida a $1 \%$ e com associação de tropicamida a $1 \%$ mais cloridrato de fenilefrina a $10 \%$.

Resultados: Os exames de biomicroscopia ultra-sônica dos olhos glaucomatosos e não-glaucomatosos, sem a insti-lação de cicloplégicos e midriáticos, não mostraram diferença significante da profundidade da câmara anterior, do toque íris-cristalino e da distância íris-zônula. A diferença entre os exames sem a instilação de midriáticos e cicloplégicos, com tropicamida a 1\% e com associação de tropicamida a $1 \%$ mais cloridrato de fenilefrina a $10 \%$ foi estatisticamente significante nas variáveis estudadas em ambos os grupos.

Conclusões: Não foram observadas diferenças anatômicas entre o segmento anterior dos olhos glaucomatosos e nãoglaucomatosos após o uso de drogas midriáticas e cicloplégicas. Os resultados desta investigação clínica usando a biomicroscopia ultra-sônica foram inovadores, permitindo uma avaliação dinâmica e quantitativa das relações ana-tômicas entre as estruturas intra-oculares quando subme-tidas à midríase e cicloplegia, que até então eram somente qualitativas.
Palavras-chave: Segmento anterior do olho; Ultrasonografia; Glaucoma; Ângulo aberto; Midriáticos; Cicloplégicos.

\section{REFERENCES}

1. Jensen PK, Rask R, Olsen T. Video controlled M-mode biometry. Acta Ophthalmol Scand 1995;73:61-5.

2. Pavlin CJ, Harasiewicz K, Foster FS. Ultrasound biomicroscopy of anterior segment structures in normal and glaucomatous eyes. Am J Ophthalmol 1992;113:381-9.

3. Allemann N. Biomicroscopia ultra-sônica. Arq Bras Oftalmol 1995; 58:283-5.

4. Pavlin CJ, Foster, SF. Ultrasound biomicroscopy of the eye. $1^{\text {st }}$ ed. New York: Springer-Verlag, 1995.

5. Pavlin CJ, Foster SF. Ultrasound biomicroscopy in glaucoma. Acta Ophthalmol 1992;204 (suppl.):7-9.

6. Portney GI, Purcell TW. The influence of tropicamide on intraocular pressure. Ann Ophthalmol 1975;7:31-4.

7. Siegel S. Estatística não-paramétrica para as ciências do comportamento. São Paulo: Mc Graw-Hill, 1975.

8. Pavlin CJ, Easterbrook M, Harasiewicz K, Foster FS. An ultrasound biomicroscopic analysis of angle-closure glaucoma secundary to ciliochoroidal effusion in IgA nephropathy. Am J Ophthalmol 1993;116:341-5.

9. Pavlin CJ, Foster FS. Ultrasound biomicroscopy in glaucoma. In: Ritch R, Shields MB, Krupin T, edit. The glaucomas. Basic Science. 2.ed. St. Louis: Mosby Year Book, 1996:1.471-90.

10. Bezzina AM. Ultrasound biomicroscopy of anterior segment structures in normal and glaucomatous eyes. Am J Ophthalmol 1992;114:516-7, (Letter).

11. Mindel JS. Cholinergic pharmacology (1988). In: Tasman W, Jaeger EA, edit. Duane's foundations of clinical ophthalmology. Philadelphia: J.B. Lippincott 1994;3:26-59.

\title{
ENCONTRO ANUAL DA ACADEMIA AMERICANA DE OFTALMOLOGIA
}

\section{1 a 25 de Outubro de 2000}

\author{
DALLAS - TX
}

Informações: American Academy of Ophthalmology

P.O. Box 7417 - San Francisco - CA 94120-7424

Tel.: (415) 561-8500 • Fax: (415) 561-8533

\section{A home page da Academia, com o respectivo e-mail, pode ser acessada a partir da home page do CBO: http://www.cbo.com.br}




\title{
XIV Congresso Brasileiro de Prevenção da Cegueira e Reabilitação Visual
}

\author{
6 a 9 de Setembro de 2000 \\ Centro de Convenções de Natal - RN
}

TRABALHOS PREMIADOS

- Prêmio Conselho Brasileiro de Oftalmologia

"Proposição de um modelo experimental para estudo de vasos e células em esclera de coelhos"

Autores: Suzana Matayoshi, Ruth Miyuki Santo, Milton Ruiz Alves, Vera C. Delmonte, Paulo Hilário Saldiva.

\section{- Prêmio Oftalmologia Cirúrgica}

"Membrana amniótica no tratamento dos afinamentos córneo-esclerais"

Autores: Daniella V. B. Fairbanks Barbosa, Luiz Antônio Vieira, Walner Darlos dos Santos, Greicie Attie, José Álvaro Pereira Gomes, Denise de Freitas.

\section{- Prêmio Oftalmologia Clínica}

"Imunofluorescência direta para pesquisa de Chlamydia trachomatis em portadores de conjuntivite alérgica"

Autores: Cinthia Mendonça de Melo, Maria Cristina Nishiwaki-Dantas, Tânia Guidugli, Simone Finzi, Paulo Elias Correa Dantas.

\section{- Prêmio Pesquisa Básica}

"Alterações morfométricas e ultraestruturais do nervo óptico em ratos induzidos a alcoolismo crônico"

Autores: Alvio Isao Shiguematsu, Silvana Artioli Schellini, Cláudia Helena Pellizzon, Carlos Roberto Padovani, Elisa Aparecida Gregório.

- Prêmio Pesquisador Internacional

"Ultraestrutura da interface vítreo-retiniana"

Autores: Flávio Attanasio de Rezende, David Chow, Michael Kapusta, André Maia, Miguel Burnier Jr.

\section{- Prêmio Prevenção da Cegueira}

"Condições de adaptação e venda de lentes de contato em óticas do Estado de São Paulo"

Autores: Andrea Cotait Kara José, Kátia Gargiulo da Cunha, João B. N. S. Malta, Ana Carolina Marcelo Gomes, Fernando Novelli.
- Prêmio Região-Centro-Oeste

"Saúde ocular para o trânsito"

Autores: Carlos Sérgio Melo, Jane Paulino Borges, Lúcio Moraes, Alan Rassi, Marcos Ávila.

- Prêmio Região-Nordeste

"Prevalência de hipertensão arterial em pacientes submetidos à cirurgia de catarata"

Autores: Andréa Gifoni Siebra de Holanda, Ana Danielle de Mello Tavares, Antônio Guilherme Ventura, Albert Dickson de Lima, Ronald Fonseca Cavalcanti.

- Prêmio Região - Norte

"O perfil da saúde ocular dos pacientes atendidos pelo serviço de oftalmologia do Programa de Saúde da Família do Município de Manaus - Amazonas"

Autores: Randolpho Castro de Araújo, Paulo Roberto Magalhães Silva, Rosângela Rufino Mendonça, Heliana Nunes Feijó Leite, Marilene Fernandes Maia.

\section{- Prêmio Região-Sudeste}

"Tratamento da hemorragia vítrea experimental com perfluorpropano: resultados finais"

Autores: Paulo Augusto de Arruda Mello Filho, Octaviano Magalhaes Jr., José Augusto Cardillo, Paulo Henrique Morales, Jorge Mitre, Michel Eid Farah.

- Prêmio Região - Sul

"Estudo do nível de conhecimento de pacientes glaucomatosos sobre seu diagnóstico comparado a hipertensos e diabéticos"

Autores: Silvane Bigolin, Agostinho Bryk Jr., Maria Claudia Gomes Komatsu, Lisandro Sakata, Leciana Rorato Chiconelli Vanzo. 